\title{
The effects of six beat kick technique training on swimming speed for the $\mathbf{5 0}$ meters freestyle
}

\author{
Meiriani Armen ${ }^{1, *}$ \\ ${ }^{1}$ FKIP, Universitas Bung Hatta, 25176, Padang, Indonesia
}

\begin{abstract}
Freestyle is one of the main swimming styles taught to swimmers. It has various techniques from stroke and breathing to limbs moving and coordinating. The legs moving technique Six Beat Kick is one of the techniques that could make an athlete swims faster. A quasi eksperiment research with pre-test and post-test program is aimed to recognise the impacts Six Beat Kick technique training on swimming speed for the 50 meters freestyle. This research is carried out in G-Sport Center Swimming Club in Padang city. The sampling method uses purposive sampling with 20 participants. The data are collected from swimming speed test on 50 meters freestyle. Prior the training, a pre-test is conducted. Then, the athletes must follow the training program for 14 times of training. Lastly, a post-test is performed. In addition, an analysis condition testing and a research hypothesis testing use data normality test and t-test with significance level of $\alpha 0,05$. From the analysis condition testing, it could be assessed that the data follow a normal distribution with $\mathrm{L}_{\text {counted }} 0,108<\mathrm{L}_{\text {table }} 0,190$. The hypothesis testing has a significant impact on swimming speed for 50 meters freestyle acknowledged from $t_{\text {counted }}$ $22,19>t_{\text {table }} 1,73$. It can be concluded that Six Beat Kick technique training program could improve the swimming speed of meters freestyle.
\end{abstract}

\section{Introduction}

Swimming has been recognized as one of the mosthelpful sports for a long time as the ancient peoples must be able to conquer nature. Since then, swimming has evolved and beenone of the popular water sports [1]. In Indonesia, swimming as a whole has also been gaining its popularity because it has been introduced to the people from kindergarten up to college level.

The objectives of Indonesians to swim are as recreational, educational, therapeutic and competitive events. In addition,the chance for a person to swim also comes in many ways [2]. They could swim by themselves, family and through swimming coaching. "Swimming is a sport done in water through coordinated movement of the limbs, the body, or both"[2]. There are four swimming styles that must be mastered, namely free style, backstroke, butterfly and breaststroke style [3]. Swimming is measured by the time counted in a game which means to measure the time a start system and finish detection system are

\footnotetext{
*Corresponding author: ria.pjkr12@bunghatta.ac.id
} 
required. The faster an athlete swims the better the time it takes. Defines the speed as the ability to move from one place to another in the shortest time possible [1].

In regional level, the development of swimming in West Sumatra is quite good with the swimming organizations, clubs or groups being fostered and organized by PRSI [4]. The number of swimming clubs in the city of Padang is quite numerous and has lots of talented athletes. But because of some obstacles, there are athletes who cannot practice maximally and cannot perform well. Existing obstacles are 1) Improper training program 2) Monotonous practice methods 3) Inadequate infrastructure facilities. One of the clubs in Padang that continues to actively improve swimming performance is G-sport Center Swimming Club

Swimming exercise should be performed continuously and persistently as it will be seriously affecting the technical changes of the athletes and hopefully the athletes can bring good achievements for West Sumatra. Freestyle is one of the main swim styles taught to swimmers. Logically, the movement of the swimmers' legs is in accordance with the motion of cycling [5]. For freestyle, or front crawl leg kick (a simultaneous up and down kick) the knees bend only slightly to give the legs a relaxed kicking action [6]. But freestyle (crawl) has its own difficulty when taking a breath because the movement of the head should turn to the right side or left. In a simple technique freestyle pool is: 1) Body position, 2) Foot movement, 3) Hand movement, 4) Taking a breather, 5) Coordination [7].

In order to smooth the implementation of the freestyle, then an athlete must a knowledge the appropriate techniques in order to create optimal results in accordance with the style taught in the training program. One of freestyle technique trainings that will be provided is Six Beat Kick.

The Six Beat Kick is nearly always used by short-distance swimmers but is also popular with middle distance swimmers and long distance swimmers but with a somewhat subdued kick. In short, the swimmer should complete six kicks per stroke cycle or three kicks per single arm stroke which allows the movement results a powerful propulsion [8]. Given this, it benefits the swimmers in both the exercises and the race. This form of technique is an inseparable part of freestyle which in this study is observed in 50 meters freestyle (short distance / sprint).

\section{Method}

This research method uses quantitative research with experimental approach, one group pretest posttest design [9]. Quasi experiments are used because it is difficult to get the control group as a comparison group in this study. Prior the study, a pretest related to Six Beat Kick is conducted and continued with a posttest.

The sampling technique used in this study is Purposive Sampling [9], that consisted of 20 male participants of the 40 athletes who are sons/daughters of the beginner group category and achievements from G-Sport Center Swimming Club Padang in accordance with certain considerations. The study is conducted in G-Sport Center swimming pool while the treatment is carried out for 16 times with exercise frequency 4 times a week. The exercise is started in the afternoon at 16.00 WIB.

The instrument used in this research is 50 meters freestyle after going through the training process using the technique of Six Beat Kick measured as far as 50 meter which are viewed based on the fastest time result. The hypothesis of this study is there is a significant effect of Six Beat Kick technique exercises on 50 meters freestyle. The testing of requirements analysis and research hypothesis uses data normality test and t-test with significance level $\alpha 0,05$. 


$$
t=\frac{|x 1-x 2|}{\sqrt{\frac{\sum D^{2}-\frac{\left(\sum D\right)^{2}}{n}}{n(n-1)}}}
$$

\section{Result and discussion}

Deskription data from the results of the pretest, it can be obtained the range 38.55 seconds to 58.10 seconds with a mean time 48.63 seconds and standard deviation 4.98. From this frequency distribution table, it can be seen that the result of the pretest is in Poor category.

Table 1.Frequency distribution in pretest of six beat kick technique

\begin{tabular}{|c|c|c|c|c|}
\hline No & Interval & Fi & $\%$ & Category \\
\hline 1 & $38,55-42,60$ & 3 & 15 & Very well \\
\hline 2 & $42,61-46,92$ & 4 & 20 & Good \\
\hline 3 & $46,93-50,24$ & 5 & 25 & Medium \\
\hline 4 & $50,25-54,56$ & 5 & 25 & Less \\
\hline 5 & $54,57-58,88$ & 3 & 15 & Less once \\
\hline & & 20 & 100 & \\
\hline
\end{tabular}

As for the posttest, the results obtained range 33.28 seconds to 54.85 seconds with a mean time 43.66 seconds and the standard deviation 5.32. From this frequency distribution table, the posttest result of Six Beat Kick technique is in moderate category.

Table 2. Frequency Distribution in posttest of Six Beat Kick Tekhnique

\begin{tabular}{|c|c|c|c|c|}
\hline No & Interval & Fi & $\%$ & Category \\
\hline 1 & $33,28-37,60$ & 2 & 10 & Very well \\
\hline 2 & $37,61-41,92$ & 6 & 30 & Good \\
\hline 3 & $41,93-46,24$ & 7 & 35 & Medium \\
\hline 4 & $46,25-50,56$ & 2 & 10 & Less \\
\hline 5 & $50,57-54,88$ & 3 & 15 & Less once \\
\hline & & 20 & 100 & \\
\hline
\end{tabular}

From the data of pretest and posttest, it can be observed an improvement, from mean pretest 48.63 to 43.66 at posttest, and the standard deviation at pretest of 4.98 becomes 5.32 at posttest. Research data is tested in the normality test by using the Lillieforstest with the accepted criteria that the data distributed normally if Lo $<$ Ltable for $n=20$ with the real level $\alpha=0.05$.

Table 3. The Summary of Normality Test Results

\begin{tabular}{|c|c|c|c|}
\hline Training & $\mathrm{N}$ & $\mathrm{L}_{\mathrm{o}}$ & $\mathrm{L}_{\text {table }}$ \\
\hline Six Beat Kick & 20 & 0.108 & 0.190 \\
\hline
\end{tabular}

From the table above, it can be seen that Lo $<$ Ltable. Then it can be concluded that the research variable is distributed normally in the real level $\alpha=0.05$.

Discussion of the results of this study is intended as an overview to facilitate draw conclusions research. Freestyle is a way of swimming that resembles an animal so called Crown Style which means crawling and freestyle is a force that performs hand movements over the surface of the water and allows moving in the water faster than with other styles. 
Six Beat kick is a technique with six leg beats per arm cycle (i.e. two strokes). This movement technique has a greater frequency of beat, so the freestyle swimmers can learn more quickly and effectively. This technique is very well used or given to freestyle swimming athletes in doing the programmed workout. The increase of the results from before being treated and after being treated shows that the Six Beat Kick technique gives a good effect on the 50 meters freestyle swimmers. The increase can be seen from the time obtained by each athlete that increases $2-4$ seconds.

Testing the normality of the Six Beat Kick on 50 meters freestyle uses Lilliefors Lcount $<$ Ltable, and the data is normally distributed and vice versa. From the test, it can be obtained Lcount $=0.108$ for Label at significance level $\alpha=0.05$ is 0.190 . From the test results above, it can be concluded that the data is normally distributed. To perceive the available significance data then t-test is used. The test criterion is significant if $t_{\text {counted }}>t_{\text {able }}$. From the test results, it can also be obtained tcount of 22.19 and ttable of 1.73.

\section{Conclusion}

Six-Beat Kick has an effect on the 50 meters freestyle swimmers significantly. It can be seen from the mean time of the pretest (48.63) and posttest (43.66) which there is an increase from pretest to posttest after being treated / exercised.

1. Six-Beat Kick has an effect on the 50 meters freestyle swimmers significantly. It can be seen from the mean time of the pretest (48.63) and posttest (43.66) which there is an increase from pretest to posttest Based on the results of this study, it is advisable to the swimming coaches in Padang to provide Six Beat Kick exercise to improve the technique of the athletes.

2. To the swimming trainers who want to improve the technique and speed of their athletes, it is urged to develop an exercise development program using the Six Beat Kick technique for a freestyle program.

3. It is recommended for the researchers to conduct further studies using much larger samples, longer research time and better exercise program to increase the performance of freestyle swimmers.

Acknowledgment : This study has been tested in front of mentors and examiners in 2008

\section{References}

1. Suarta, I Wayan (2013). SWIMMING TRAINING STYLE CHEST 8 TIMES 4 SETS 25 METER POOL SET FURTHER INCREASE SPEED OF 100 YARDS THAN 4 TIMES STYLE CHEST 4 SETS 50 METER POOL SET TO BEGINNERS SON, ISSN : 2302-688X. Sport and Fitness Journal Volume 1, No. 1 : 45 - 59, Juny

2. Farokie, Latiful Khobir; Eko Hariyanto, Hariyoko (2016). THE EFFECT OF DRY LAND CIRCUIT EXERCISE MODEL AND SPRINT SPATIAL TRAINING TO CAPABILITIES OF CRAWL 50 METER STYLE SPEED, Jurnal Pendidikan Jasmani, Vol 26 No 1 April

3. Kamalia, Ahsanul (2014). THE EFFECT OF MODIFICATION OF TRAINING TECHNIQUES OF BACKSTROKE ENGINEERING ON LUMBA-LUMBA SWIMMING CLUB SURABAYA, Jurnal Kesehatan Olahraga Volume 02 Nomor 02 Tahun 2014, 106-113 
4. Surahman, Fadli (2016). EFFECT OF REPETITION METHOD AND INTERVAL INTENSIVE METHOD ON THE SPEED FREESTYLE 50 METERS, Jurnal Curricula Kopertis Wil X Vol 1, No 2 (2016)

5. Armen, Meiriani (2016). THE EFFECT OF METHOD INTENSIF INTERVAL AND EXTENSIVE INTERVALS TO SPEED FREESTYLE 50 METERS OF PEACE ATLETS TIRTA NGALAU SWIMMING KLUB PAYAKUMBUH, Jurnal Penelitian Dan Kajian Ilmiah MENARA ilmu Vol. X Jilid 2 No. 64, Februari 2016 ISSN16932617

6. Mielke, Wilhelm. 1990, RENANG, Semarang:effar ofset

7. Sukmawati, Dwi; Setyo hartoto (2015). APPLICATION OF LEARNING FREE STYLES OF FREE STYLE LEARNING RESULT FREESTYLE SWIMMING. Jurnal Pendidikan Olahraga dan Kesehatan Volume 03 Nomor 02 Tahun 2015, 366 - 370 ISSN : 2338-798X

8. Kurnia, Dadeng.1987, Pedoman Melatih Renang, Jakarta;Diktat

9. Rubiansyah, Aziz; Agus Rusdiana, R. Boyke Mulyana (20150. THE EFFECT OF EXERCISE PLYOMETRICS ON THE RESULT OF REJECTED START AT SPORTS SWIMMING, Jurnal Terapan Ilmu Keolahragaan 2015 Vol .02 No.02 Hal 6-11

10. Strzała Marek, Aleksander Tyka, Piotr Krężałek (2014). Physical Endurance and Swimming Technique in 400 Metre Front Crawl Race. Journal of Human Kinetics volume $182007,73-86$ 